Reserch Artide

JOURNAL OF THE CAMEROON ACADEMY OF SCIENCES Vol. 14 No. 3 (JANUARY 2019)

\title{
Electrical resistivity tomography of the Douala-Massoumbou Paleocene- E ocene aquifer (Cameroon Atlantic Margin)
}

Mbida Yem¹, J. Q. Yene Atangana', S. P. Koah Na Lebogo", M.F. Mienlam Essi ${ }^{1}$

${ }^{1}$ University of Yaoundé I, Faculty of Science, Department of Earth Sciences, Yaoundé-Cameroon.

Email: yem04@yahoo.com (Corresponding author)

\begin{abstract}
ABST RACT
The Paleocene aquifer of the D ouala-Massoumbou sub basin is a rhythmic sequence of sand and shale deposits. Resistivity pseudosections and profiles of half-distance between current electrodes of $350 \mathrm{~m}$ were acquired at 20 different sites of the D ouala-Massoumbou subbasin. These data coupled with mud and gamma-ray logging of deep groundwater boreholes led to the identification of two major sand sequences through the Paleaocene-Eocene stratigraphic section. The upper sequence associated with Ypresian 30-50 m thick unconformity made up with semi-conductive records, is punctuated by lenses of substantially water bearing sand (WBS). While the lower sequence locally associated with H2S and iron pollution plumes, displays high conductive records. In such sequences, the distribution of sand and clay deposits settled by channel incision appears fundamental in predicting reservoir geometry and the hydrological potential of the Paleocene WBS.
\end{abstract}

Keywords: Sag basin, electrical tomography, Paleocene formation, water-bearing sand.

\section{Résumé}

L'aquifère du Paléocène du sous-bassin de D ouala-Massoumbou est une séquence rythmique de dépôts de sable et d'argile. D es sondages géoélectriques tripole $(\mathrm{OA}=350 \mathrm{~m})$ et des tomographies de résistivité ont été acquis sur 20 sites différents de la zone de faible enfouissement de cet aquifère. Ces données, couplées aux résultats des diagraphies gamma-ray et des déblais des forages hydrogéologiques profonds, ont permis d'identifier deux séquences de sable hydrostratigraphique au sein de l'aquifère paléocèneéocène. La séquence supérieure semi-conductrice correspond à dépôts de sable aquifère sain, épaisse de 30 à $50 \mathrm{~m}$ et associés à la discordance ypresienne. La séquence inférieure très conductrice, correspond à des chenaux de sable aquifère pollué par le sulfure d'hydrogène (H2S) et le fer. La mise en corrélation de l'ensemble des résultats obtenus a permis de constater que la prise en compte du développement spatial des chemins hydrologiques fossiles est un critère fondamental pour la prédire la distribution et l'exploitation des niveaux de sable aquifère sain du Paléocène du sous-bassin de D ouala-Massoumbou.

Mots clés: Bassin de fossé d'éffondrement, tomographie électrique, Formation paléocène, Sag basin, electrical tomography, Paleocene formation, niveaux de sable aquifère sain.

\section{Received: 06/ 08/ 2018 \\ Accepted: 05/ 12/ 2018 \\ D0I: https:/ / dx.doi.org/ 10.4314/ jcas.v14i3.5}

(C) The Authors. This work is licensed under the Creative Commons Attribution 4.0 International Licence. 


\section{INTRODUCTION}

According to Regnoult (1986), the Paleocene to Recent sedimentary cover of the DoualaMassoumbou Subbasin appear as a thick series of shale deposits (Fig. 1) with intercalated layers of sand that denotes a turbidite sequence. Many studies of this sequence have been carried out in terms of their petroleum and hydrogeological potential (D umort, 1968; Chiarelli, 1978). In relation to its hydrogeological resources, records of pressure and well-logging analysis (Chiarelli, 1978) have shown that the Paleocene of the Eastern D ouala-Massoumbou sag basin is divided into two layers: upper clayey sand (CS) and lower sand over clay (SO C).

From Martin (1979), the thickness of the Paleocene SO C sequence in the RZ2 borehole is about $100 \mathrm{~m}$, while its uppermost part is made up of a dark shale layer. To the West of the RZ2 borehole, the Paleocene SO C sequence gives way to a marine unit which is basically clayey. It appears that, the rework of basement faults (i.e. Logbesou and Bisombè flexure) has an influence on the sand distribution during the Paleocene SO C deposition (Regnoult, 1986). By the same token, the intercalations of colluvial deposits in the Cenozoic sequence as well as in the other series were recognized (Martin, 1979). However, given the results of water chemical analysis (BRGM, 1981), it has been suggested that the Paleocene SOC sequence might represent the most interesting hydrogeological prospect of the D ouala sag basin. Thereafter, the groundwater supply project of the Douala neighborhood, including 9 deep monitoring and 12 pumping wells (greater than $30 \mathrm{~cm}$ in diameter) have been carried out along the Dibamba-Masoumbou border (Fig. 1). In as much as this project produced flow rate lower than predicted, further investigations by BRGM (1983) and Frey (1985) have also revealed lateral and rapid variations of the Paleocene SOC lithofacies.

Foregoing, the purpose of this paper is to help the reader to better understand the depositional setting and sediments distribution within the Paleocene SOC layer or aquifer. We interpret and discuss the Paleocene SOC electrical resistivity in the light of post well-logging and provide keys elements for the Douala-Massoumbou groundwater assessment.

The study area covers the eastern part of the D ouala sag basin (Fig. 1). Morphologically, the topography is undulating and comprises submeridian ridges attaining $100 \mathrm{~m}$. From a geodynamic point of view, the D ouala sag basin is a faulted structure with a N045 direction. Its origin and evolution are related to basement dilatancy in response to transcurrent faulting between the Beti-Fang and Brazilian-WestAfrican plates (Reyre, 1984; Nely \& Vaillant, 1993; Mbida, 2012).

Correlation between boreholes data have helped to reconstruct the regional hydrogeological crosssection (Fig. 2) of the D ouala sag basin. Following groundwater studies (Martin, 1979; BRG M, 1981; BRG M, 1983; Frey, 1985 and Mbida, 2004), it has been suggested that the Paleocene aquifer represent the most interesting prospect of the D ouala sag basin. To improve knowledge concerning the hydraulic potential of this prospect, resistivity pseudosections and profiles have been acquired within and along the Paleocene-Holocene deposits. 


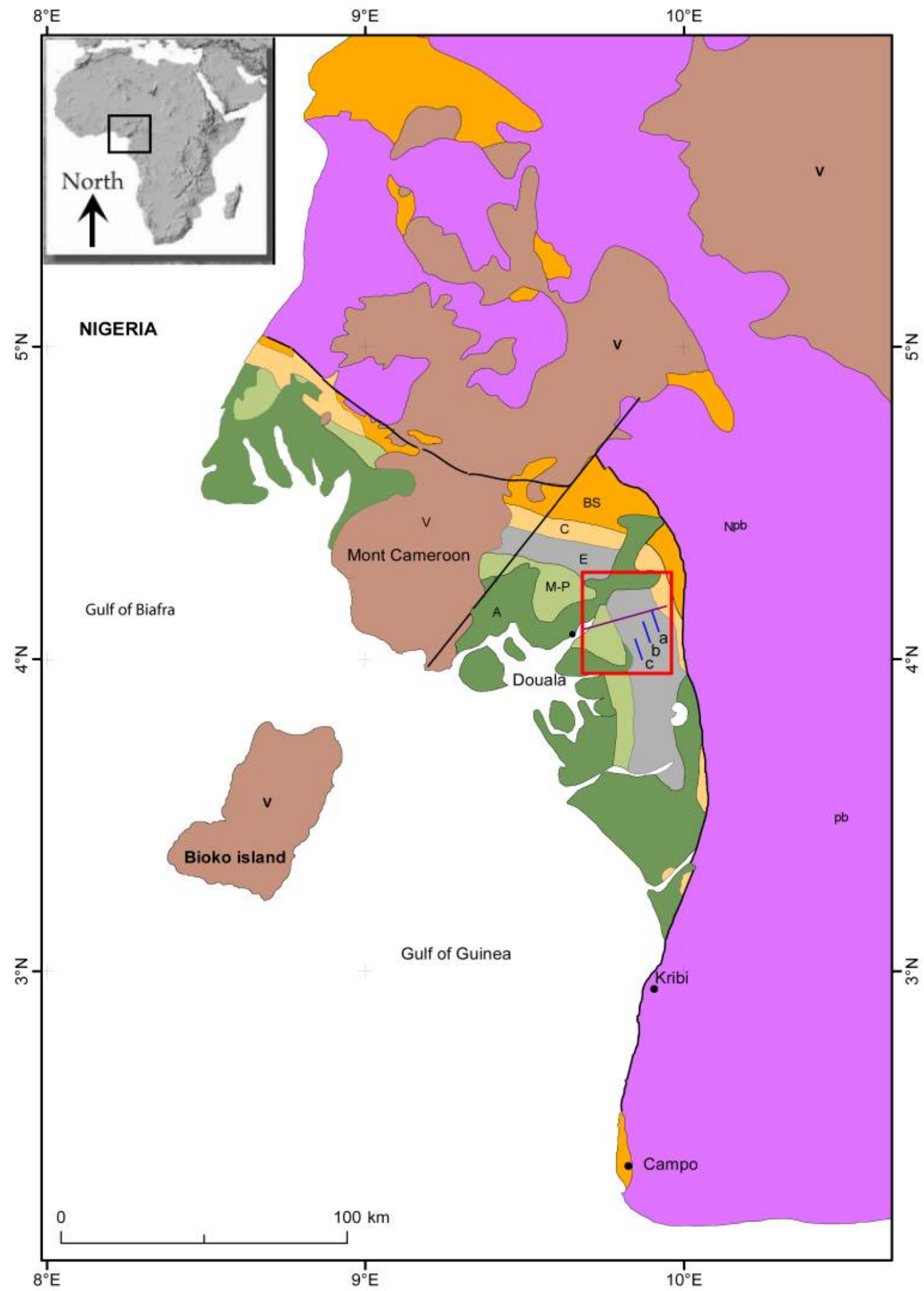

Fig. 1. Map of Cameroon Atlantic basin (redrawn and modified from Martin, 1979). The regional geology (color area) is modified from Dumort (1968). Tectonic features are shown according to Mbida (2012). Red square: study area containing the location of regonal hydrogeology cross-section of figure 2 (purple line) and resistivity pseudosections of figure $3(a, b \& c$ blue line); blank space: offshore area and Nigerian domain, thick solid lines: Prominent features and active faults; thin solid lines: surface contour. Caption letters: Npb: Neoproterozoïc, BS: basal sandstone, C: Middle and late Cretaceous, V: volcanic rocks, E: Eocene-Paleocene, M-P: Miocene-Pliocene, A: Holocene alluvial deposits. 
REVUE DE L'ACADEMIE DES SCIENCES DU CAMEROUN Vol. 14 No. 3 (Janvier 2019)

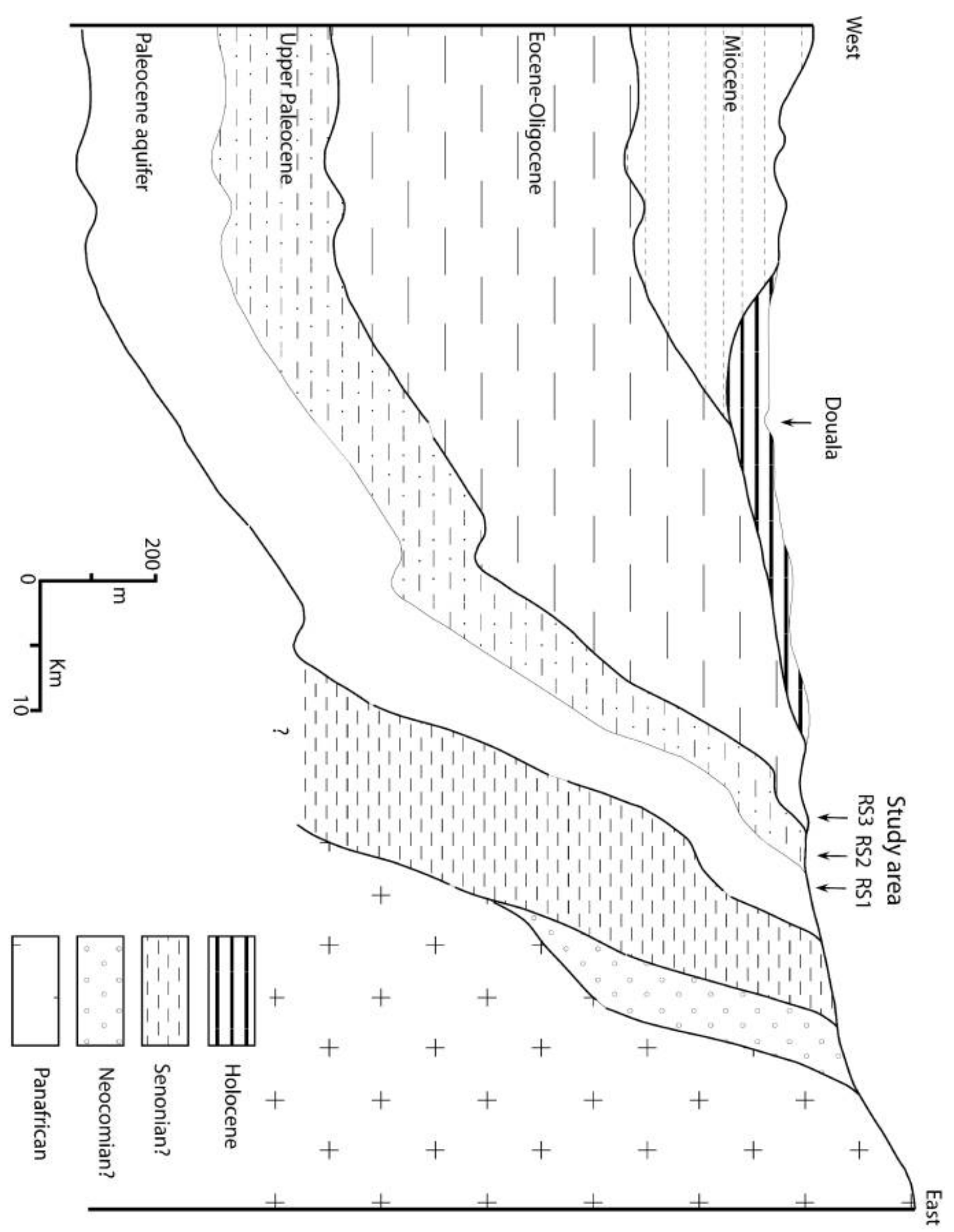

Fig. 2. Regional hydrogeology cross-section of the Douala-Massoumbou Sag Basin showing the location of the study area and upright deeping of the Paleocene aquifer (redrawn and modified from Martin, 1979). Caption letter: RS: resistivity pseadosetions (1, 2 \& 3). 


\section{MATERIALS AND METHODS}

Preliminary project of field data acquisition involved site recognition and survey design setting. Following this program, geophysical lines including vertical sounding (VES) and multidimensional pseudosections (MPS) were acquired along 7 localities.

To increase survey data accuracy, VES to welllog calibration was first performed. Accordingly, field measurements were carried out using Schlumberger electrode configuration (Halvorson \& Rhoades, 1976; Barker, 1989; Pozdnyakov et al. 1996; Banton et al., 1997), with a maximum current spacing of $750 \mathrm{~m}$. For MPS imaging survey (Marescot et al., 2003) data were taken with three cable sets of potential difference along a trace of line. Following field investigations, processed pseudosections and surface contours were generated using the least-squares inversion program (Loke, 1995; Loke and Baker, 1996) and geological modeling.

\section{RESULTS}

Detail analysis of the resistivity pseudosections led to the identification of tree layers labeled: L1, L2 and L3 (Fig. 3) through the Paleocene formation. L3 appears as a thick resistant sequence with significant low conductive anomalies. Underlain by a top-discordant relation, L2 displays linear shaped patterns with local variation of thickness and a resistivity range from 250 to $610 \&$ !.m. L1 seems to be a thick and folded conductive sequence with resistivity records lower than $150 \&$ !.m.

Together, results from post wells logging (Fig. 4) show that L2 (Paleocene SO C) and L3 (Paleocene CS) electrical patterns corresponded to clastic sequences (Pettinggill \& Weimer, 2002; Carvajal et al., 2009; Covault et al., 2011) with prominent water-bearing sand. Because of its electrical and large-scale folded pattern, we interpreted L1 as the over pressured shales of the Nkapa Formation (Reyre 1981; Regnoult, 1986).

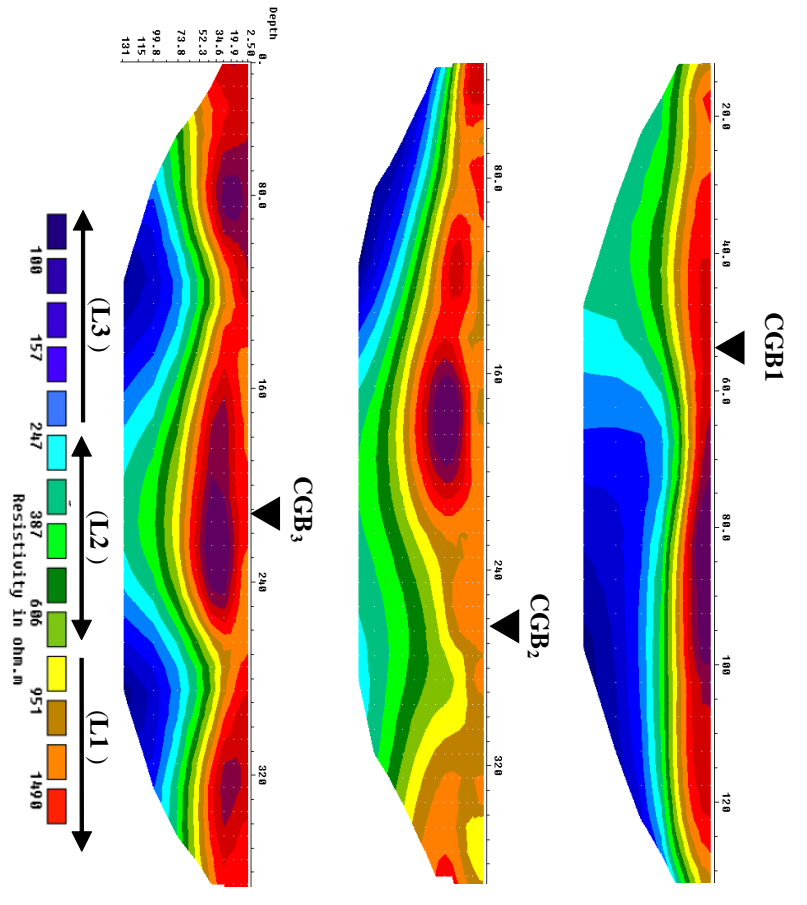

Fig. 3. Resistivity pseudosections of the Paleocene aquifer showing the location of pumping well (PW) that have been drilled according to field geophysical investigations. Caption letters: RS: resistivity pseadosetions (1, 2 \& 3); CGB: calibrated gaundwater borthdes (1, 2 \& 3); L (1, 2 \& 3): Paleccene aquifer layer interprated according to resistivities records and bohdeles logging ( æefigure 4).

As shown in figure 4, the Upper Paleocene aquifer (CS) is composed of interbedding red shaly sand and shale layers, while the lower Paleocene aquifer (SO C) exhibits grey to white sand bank over clayey units. Given these colorations, it appears that the sedimentary regime during the Paleocene CS accumulation was dominated by stepped sea level regression, while the Paleocene SOC deposition was controlled by a basin wide transgression episode (Reyre 1981; Regnoult, 1986). Following this assumption, relationships can be viewed with the presence of $\mathrm{H}_{2} \mathrm{~S}$ and iron pollution plumes occurrence within the UPA (BRGM, 1981; BRG M, 1983; Frey, 1985). 


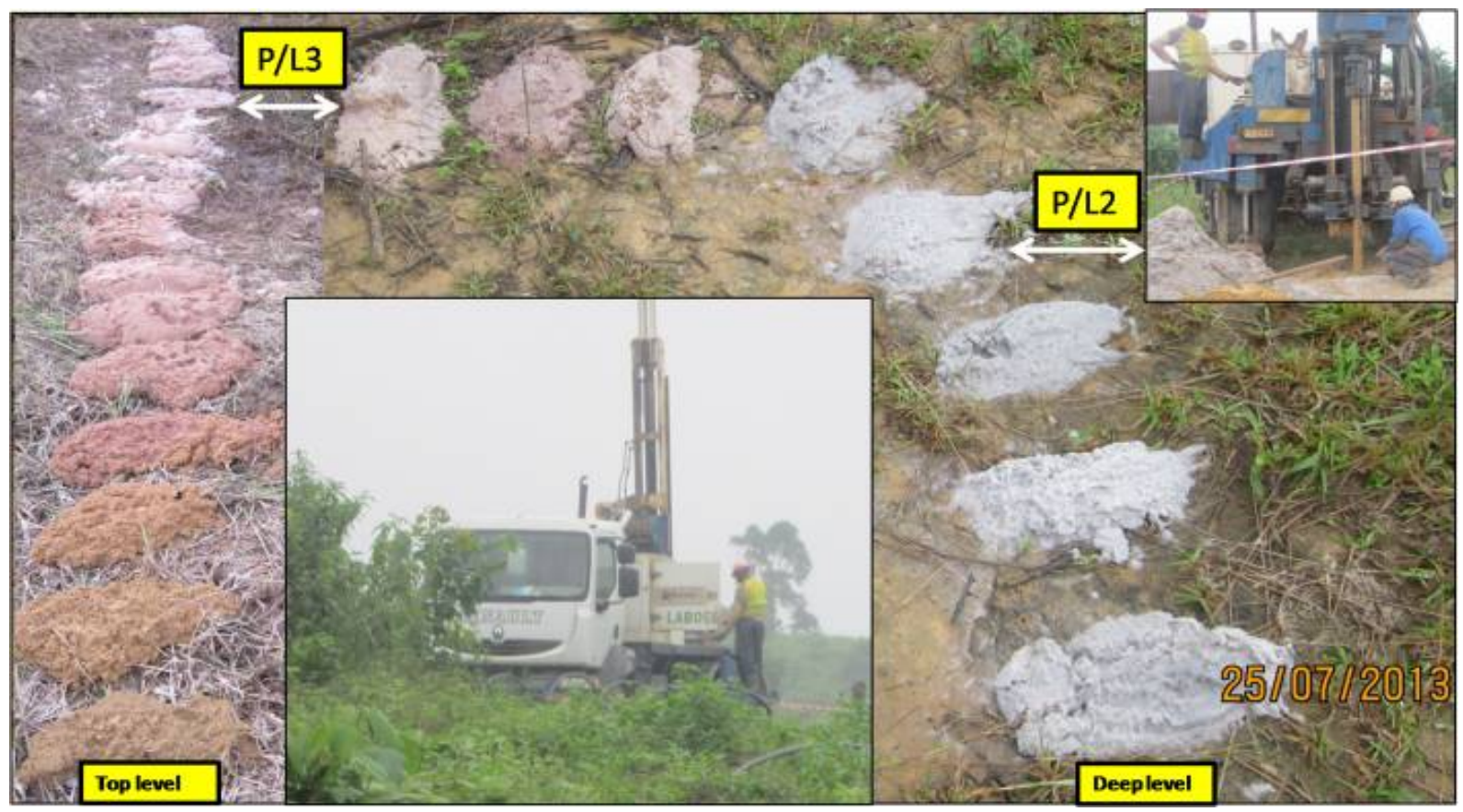

Fig. 4. Well logging photography of the Holocene-Paleocene sequence. D ouble arrow: interpreted sequence. Caption lettes: P/ L2: Paleocene aquifer layer 2, P/ L3: Paleocene aquifer layer 3. Note red brick color on contact between P/ L2 and P/ L3 that can refer to erosional unconformity.

\section{DISCUSSION AND CONCLUSION}

In keeping with water chemical analysis (Frey, 1985; Labogenie, 2013), the present study shows that the Paleocene SOC represent the major water-bearing unit of the Douala-Massoumbou sag basin. However, results from geological modeling (Fig. 5) indicate that its depositional system is associated with channel incision and by time-space migration of stream bed (Salvador et al., 2005; EL G hachi, 2007). This result provides a relatively complete and readily dated record of depositional setting, spatial distribution and structure of the Paleocene aquifer, compared to previous studies (Martin, 1979; BRG M, 1981; BRG M, 1983; Frey, 1985 and Mbida, 2004).

Apart from hydrogeology, the present study indicates that $\mathrm{CO}_{2}$ and methane gas records within the LPA might be link to deep hydrocarbon prospects. Despite the low penetration of processed pseudosecctions, the results in this paper (study) show highlighted significant disparities within the Paleocene aquifer. Improved understanding of this variability could significantly affect the economic development or exploitation of LPA hydrogeological resources, and urge an assessment of site conditions before boreholes setting.
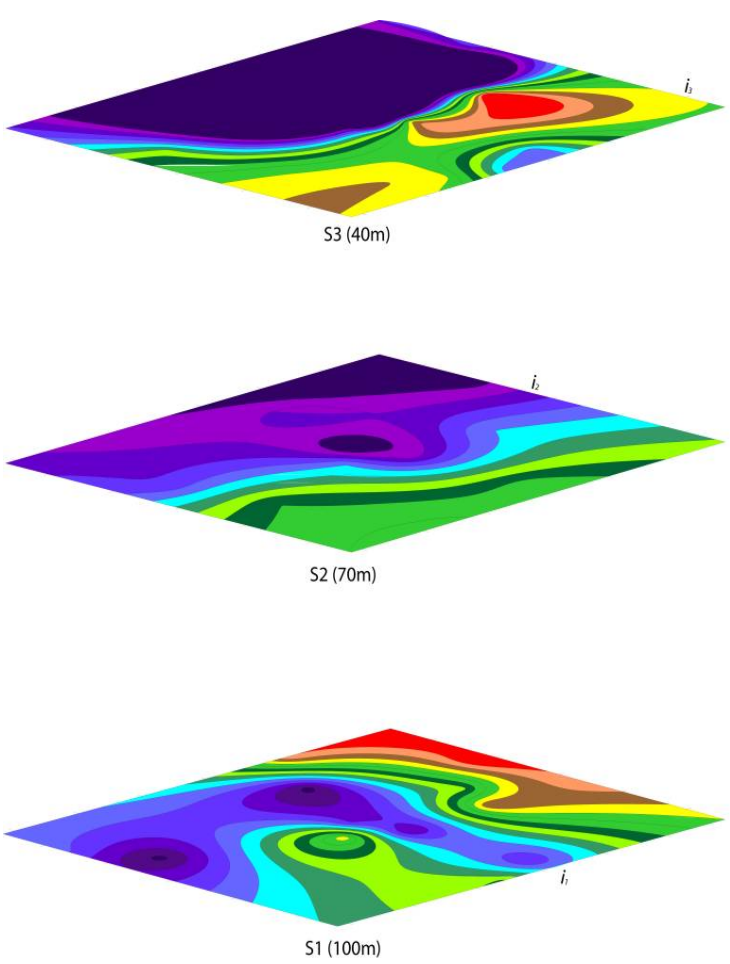

Fig. 5. Isoapparent resistivity maps of the Paleocene aquifer. Color scale values are given in figure 3. Caption letter: S: surface contar (1, 2 \& 3); i: intepreted dhannd inised axis (1, 2 \& 3). 


\section{ACKNOWLEDGEMENTS}

The use of LABOGENIE equipment is gratefully acknowledged. The authors thank Dr. G hogomo Mbih Paul for their commented on the early versions of this manuscript

\section{REFERENCES}

Banton, O., Seguin M.K. and Cimon M.A. 1997. Mapping field-scale physical properties of soil with electrical resistivity. Soil Sci. Soc. Am. J. 61:1010-1017.

Barker, R.D. 1990. Improving the quality of resistivity sounding data in landfill studies. In S.H. Ward (ed). "G eotechnical and environmental geophysics. V. 2. Environmental and groundwater applications". 245-251.

BRGM 1981. Alimentation en eau potable de la ville de D ouala à partir des eaux souterrainesfaisabilité d'une exploitation en bordure de la Dibamba-Texte. Rapport BRGM 81 AGE 021.

BRG M 1983. Alimentation en eau potable de la ville de D ouala à partir des eaux souterrainesRéalisation du dispositif d'exploitation-Texte, édition provisoire. Rapport BRG M 83 AGE 031.

Carvajal, C. et al. 2009. Sediment supply: The main driver of shelf-margin growth. EarthScience Reviews 92, 1-33.

Chiarelli, A. 1978. Étude des nappes aquifères profondes du bassin de Douala (Cameroun). Contribution del'hydrogéologie à la connaissance d'un bassin sédimentaire et à l'exploration pétrolière. ELF-R. E. Paris, France.

Covault, J. A. et al. 2011. Terrestrial source to deep-sea sink sediment budgets at high and low levels: insights from tectonically active Southern California. Geology 39, 619-622.
D umort, J.P. 1968. Notice explicative sur la feuille de D ouala-O uest. Direction des Mines et de la Géologie du Cameroun, Yaoundé. 69p.

EL Ghachi M. 2007. «La Seille: mode de fonctionnement hydrodynamique sous influence anthropique, évolution historique et tendance actuelle». Thèse de géographie, U.P.V. Metz, 398p.

Frey M. 1985. Alimentation en eau potable de la ville de D ouala à partir des eaux souterrainesRéalisation des forages F11 et F12-Rapport BRGM 85 CMR 067 EAU, 50p.

Halvorson, A.D., and Rhoades J.D. 1976. Field mapping soil conductivity to delineate dryland saline seeps with four-electrode technique. Soil Sci. Soc. Am. J. 40:571-574.

Labogénie 2013. Etudes hydrogéologiques de construction du forage industriel D PDC. D ocument commercial, 44p.

Loke, M.H. 1995. Res2D mod ver 2.20a 2D Resistivity Forward modeling, Malaysia.

Loke, M.H., Barker, R.D. 1996. Rapid left-squares inversion of apparent resistivity pseudosection by a quasi-newton method. G eophysical Prospecting 44, n¹: 131-152.

Marescot L. et al. 2003. Assessing reliability of 2D resistivity imaging in mountain permafrost studies using the depth of investigation index method. Near Surface Geophysics 1: 55-67.

Martin G. 1979. Alimentation en eau potable de la ville de D ouala à partir des eaux souterrainesRapport BRGM 79 AGE 021.

Mbida Yem. 2004. Étude géophysique du système aquifère multicouche paléocène du bassin de 
D ouala-Kribi/ Campo. Unpublish MSc (with Thesis), Univ. Yaounde I, 56p.

Mbida Yem. 2012. imagerie géophysique de la couverture sédimentaire des bassins offshore profonds du Nord de la Cyrénaïque et de D oualaKribi-Campo : éléments de géologie pétrolière. Co-directed Thesis, Univ. Yaoundé I-Cameroon and Univ. Nice-Sofia/ France, 161p.

Nely et Vaillant. 1993. Réinterprétation sismique après les retraitements de 1987. Synthèse géologique régionale et redéfinition des zones prospectives. Elf Serepca Report, Rio Del Rey Basin, Cameroon. 44p.

Pettingill, H. S. \& Weimer, P. 2002. Worldwide deepwater exploration and production. The Leading Edge 21, 371-376.

Phillips INC. 1990. Geologic development and hydrocarbon potential of the D ouala Basin, Cameroon. Text and Figures. 34p.

Pozdnyakov, A.I; Pozdnyakova, L.A., and Karpachevsky, L.O. 1996. Study hydrology of valley agricultural landscapes with electrical resistance methods. Proceeding of XXI Assembly European Geophysical Society, HS16 "The Hydrology of Small Agricultural Catchments", The Hague, Netherlands. 341-352.

Regnoult J.M. 1986. Synthèse géologique du Cameroun. Publ. Dir. Mines et Géo., Cameroun, 119p.

Reyre D. 1984. Remarques sur l'origine et l'évolution des bassins sédimentaires africains de la cote atlantique. Bull. Soc. Géol. France, 1984, (7), t. XXVI, nº6, 1041-1058.
Salvador P.G. et al. 2005. «Etude des enregistrements sédimentaires holocène des paléoméandres du Rhône dans le secteur des basses terres (Ain, Isère, France) ». Quaternaire, 16, (4), 315-328. 